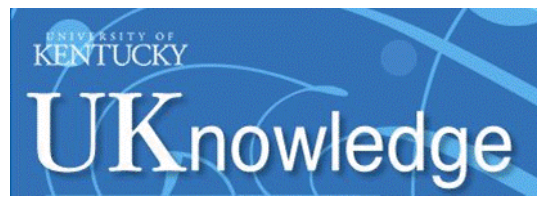

University of Kentucky

UKnowledge

Biosystems and Agricultural Engineering Faculty Publications

2018

\title{
Hydraulic Properties of Baled Switchgrass and Miscanthus
}

Drew F. Schiavone

Andrew College

Michael D. Montross

University of Kentucky, michael.montross@uky.edu

Follow this and additional works at: https://uknowledge.uky.edu/bae_facpub

Part of the Bioresource and Agricultural Engineering Commons, and the Hydraulic Engineering

Commons

Right click to open a feedback form in a new tab to let us know how this document benefits you.

\section{Repository Citation}

Schiavone, Drew F. and Montross, Michael D., "Hydraulic Properties of Baled Switchgrass and Miscanthus" (2018). Biosystems and Agricultural Engineering Faculty Publications. 223.

https://uknowledge.uky.edu/bae_facpub/223

This Article is brought to you for free and open access by the Biosystems and Agricultural Engineering at UKnowledge. It has been accepted for inclusion in Biosystems and Agricultural Engineering Faculty Publications by an authorized administrator of UKnowledge. For more information, please contact UKnowledge@lsv.uky.edu. 


\section{Hydraulic Properties of Baled Switchgrass and Miscanthus}

Digital Object Identifier (DOI)

https://doi.org/10.13031/trans.12472

\section{Notes/Citation Information}

Published in Transactions of the ASABE, v. 61, issue 3, p. 1145-1155.

(c) 2018 American Society of Agricultural and Biological Engineers

The copyright holder has granted the permission for posting the article here. 


\title{
HYDRAULIC PROPERTIES OF BALED SWITCHGRASS AND MISCANTHUS
}

\author{
D. F. Schiavone, M. D. Montross
}

\begin{abstract}
This study characterized the hydraulic properties within baled switchgrass (Panicum virgatum L., variety Alamo) and miscanthus (Miscanthus $\times$ giganteus), thereby enabling a better understanding of moisture changes in baled biomass during on-farm storage and/or high-solids bioconversion. Fully saturated bales were drained by gravity, and the moisture content was determined over 60 h. The average initial moisture content ranged between $55.9 \%$ and $71.9 \%$ (w.b.) for switchgrass and between $60.5 \%$ and $73.9 \%$ (w.b.) for miscanthus bales depending on the dry bale density. As the bale drained by gravity, rapid leaching of water was observed within the first $0.1 \mathrm{~h}$, with a reduction in moisture content of 7.3 and 7.0 percentage points (w.b.) for switchgrass and miscanthus, respectively. Leaching then continued at a steady rate until termination of the experiment, with further reductions of 4.3 and 4.4 percentage points (w.b.) for switchgrass and miscanthus, respectively. Final moisture contents after $60 \mathrm{~h}$ ranged from $45.8 \%$ to $58.3 \%$ for switchgrass and from $48.7 \%$ to $60 \%$ for miscanthus, with the higher moisture contents observed in the lowest density bales. Hydraulic conductivity tests were carried out with bales of switchgrass and miscanthus with a constant head system. The average saturated hydraulic conductivity ranged between 0.103 and $0.616 \mathrm{~cm} \mathrm{~s}^{-1}$ for baled switchgrass and between 0.219 and $0.658 \mathrm{~cm} \mathrm{~s}^{-1}$ for baled miscanthus depending on the bale density. The matric suction of baled switchgrass was also assessed at variable densities and moisture contents using the contact filter paper method. The van Genuchten parameters were found to range between 0.235 and $0.270 \mathrm{~m}^{-1}$ for $\alpha$ and between 5.415 and 10.345 for $n$, depending on the density. Infiltration tests were also carried out on baled switchgrass at variable densities and moisture contents using a minidisk infiltrometer. The curve-fitting parameters of Philip's two-term equation ranged between $0.086 \times 10^{-6}$ and $0.779 \times 10^{-6} \mathrm{~cm} \mathrm{~s}^{-1}$ for $C_{1}$ and between 0.200 and $5.805 \times 10^{-6} \mathrm{~cm} \mathrm{~s}^{-1 / 2}$ for $C_{2}$, depending on the density and moisture content. The unsaturated hydraulic conductivity ranged between 0.019 and $0.272 \mathrm{~cm} \mathrm{~s}^{-1}$, while sorptivity ranged between 0.048 and $2.103 \mathrm{~cm} \mathrm{~s}^{-1 / 2}$, depending on the density and moisture content. These results provide data required to evaluate water flow through variable-density rectangular bales and indicate a potential to remove end-products of biomass conversion from baled biomass.
\end{abstract}

Keywords. Biomass, Bioprocessing, Flushing, High solids.

$\mathrm{B}$ iomass feedstocks must be densified to improve the lignocellulose conversion into acetone-butanol-ethanol (ABE) in high-solids fermentation, particularly in terms of lowering transportation and storage costs while increasing the net calorific content per unit volume (Richard, 2010; Sahoo and Mani, 2017). A proposed on-farm high-solids conversion system would use high-density baled biomass feedstocks in a modified bunker system (Nokes et al., 2014). However, the over-accumulation of end-products inhibits bacterial growth and prevents further biodegradation during high-solids fermentation. Intermittent flushing during the fermentation process restores the bacterial production by restoring favorable conditions for

Submitted for review in June 2017 as manuscript number PRS 12472; approved for publication by the Processing Systems Community of ASABE in March 2018.

The authors are Drew F. Schiavone, former Graduate Student, Department of Biosystems and Agricultural Engineering, University of Kentucky, Lexington Kentucky, currently Assistant Professor of Regenerative Agriculture, Andrew College, Cuthbert, Georgia; Michael D. Montross, Professor, Department of Biosystems and Agricultural Engineering, University of Kentucky, Lexington, Kentucky. Corresponding author: Michael D. Montross, 128 Barnhart Building, University of Kentucky, Lexington, KY 40546-0276; phone: 859-2184319; e-mail: michael.montross@uky.edu. end-product formation (Yao and Nokes, 2014). Liquid fuels and byproducts may thereby be removed from the baled material by flushing water through the biomass.

The hydraulic properties within many baled agricultural feedstocks are currently unknown, although they are expected to play a critical role in the study of fluid flow through high-solids fermentation systems, while providing data for various storage applications. Moisture content is a critical variable for the safe and economical storage of biomass (Shinners et al., 2007; Darr and Shah, 2012; Smith et al., 2013; Sahoo and Mani, 2017). Hydraulic data within baled feedstocks would aid in the modeling of water movement due to precipitation, condensation, and other point sources during storage.

The hydraulic conductivity of baled biomass is primarily considered in the current study in order to assess the flushing potential through baled biomass during high-solids bioconversion. This proportionality constant is important in fluid flow because it defines the relationship between flux and the hydraulic gradient. In fact, hydraulic conductivity is a commonly used parameter in soil science because it describes the ease with which fluid moves through pore spaces. Hydraulic conductivity is known to be a function of the density and viscosity of the fluid as well as the intrinsic properties of the porous material itself (i.e., porosity, width, continuity, 
shape, and overall tortuosity). An assessment of the nonlinear relationship between the hydraulic conductivity and moisture content is also necessary for many of the widely used flow models, such as Richards' equation (Richards, 1931).

Hydraulic conductivity tests have previously been conducted on fibrous peat (Berry and Vickers, 1975; Lefebvre et al., 1984) and alfalfa silage (Lau and Jofriet, 1988) in a vertical orientation. Results have indicated nearly linear relationships between the logarithm of the hydraulic conductivity and void ratio, with significant effects from the packing density. Custer et al. (1990) measured the hydraulic conductivity of chopped sweet sorghum at various packing densities, soaking times, and hydraulic heads using permeameters. Soaking time and hydraulic head were found to have minimal effect on hydraulic conductivity, while packing density was found to have a significant effect. In fact, hydraulic conductivity was found to decrease by two orders of magnitude over a specified range of packing densities. A series of vertical (consolidation direction) and horizontal hydraulic conductivity tests were also performed on wholeplant corn silage (Tang and Jofriet, 1991) and alfalfa silage (Yao and Jofriet, 1992) over a range of moisture contents and void ratios. Logarithms of the horizontal and vertical conductivities varied nearly linearly with void ratio, and to a lesser extent with moisture content. The results of vertical and horizontal hydraulic conductivity were presented as functions of the porosity.

The hydraulic properties of carbonaceous fill material have also been investigated because these parameters influence the sizing of denitrification bioreactors. Saturated hydraulic conductivity has been estimated for flow through a coarse wood fill layer (Van Driel et al., 2006), wood particles (Chun et al., 2009), various types of woodchips (Christianson et al., 2010), and chopped barley straw and corncobs (Feyereisen and Christianson, 2015).

The current study aims to characterize the hydraulic properties within rectangular baled switchgrass (Panicum virgatum L. variety Alamo) and miscanthus (Miscanthus x giganteus), which have previously been identified as high-impact biomass feedstocks (Perlack et al., 2005). These specific herbaceous perennial energy crops were selected for the current study based on this criterion while allowing preliminary assessment of the hydraulic properties of two physically distinct feedstocks. Investigation of these baled feedstocks was also undertaken in the current study because previous studies were unavailable in the literature. Hence, this investigation stands to enable a better understanding of the quality of baled biomass during on-farm storage and/or high-solids conversion. In fact, the flow properties within baled biomass are expected to have a significant effect on the long-term quality of the feedstock, as well as the performance of the high-solids bioconversion process, which involves the flushing of water to remove end products (Shi et al., 2008; Selig et al., 2012; Yao and Nokes, 2014; Alvarado-Morales et al., 2015; Xie et al., 2016). This processing method may involve the loading of baled energy crops into a bunker reactor that is equipped with a false floor to allow liquid to drain beneath the bale for the removal of lignin degradation products, organic acids, and solvents by percolating water or media through the reactor (Nokes et al., 2014).

This study specifically involves an assessment of the (1) saturated moisture content, (2) leaching behavior, (3) saturated hydraulic conductivity, (4) unsaturated hydraulic conductivity, and (5) sorptivity of baled switchgrass and miscanthus. The effect of bale density on the hydraulic properties of each bulk material was also investigated in this study. The assessment of these hydraulic parameters verifies the feasibility of flushing water through baled biomass and could, therefore, be useful in the design of a reliable and effective flushing process for the bioconversion of baled feedstocks. Hydraulic data within baled feedstocks would also aid in the modeling of water movement due to precipitation, condensation, and other point sources during storage. In fact, dry matter loss (DML) has been shown to be one of the most sensitive parameters influencing the storage cost of energy crops (Sahoo and Mani, 2017). The DML of any biomass is largely dependent on the moisture content of the material, with higher moisture contents being more susceptible to colonization by mold and fungi (Richardson et al., 2006). Hence, an understanding of the hydraulic conductivity within baled feedstocks would be particularly relevant to many different storage applications.

\section{Materials ANd Methods}

Switchgrass (Panicum virgatum L., variety Alamo) and miscanthus (Miscanthus $\times$ giganteus) were harvested at the University of Kentucky Spindletop Research Farm near Lexington, Kentucky ( $\left.38^{\circ} 8^{\prime} \mathrm{N}, 84^{\circ} 31^{\prime} \mathrm{W}\right)$ in March 2013. Standard farm practices were carried out during cultivation of each feedstock type. The feedstocks were cut with a New Holland H6830 disc mower (with no conditioning rolls) at a height of approximately $15 \mathrm{~cm}$ (6 in.). Due to the time of year, the crop was dry and was immediately baled with a New Holland BC5070 baler (New Holland North America, Inc., New Holland, Pa.). Small rectangular bales $(\sim 102 \mathrm{~cm} \times$ $46 \mathrm{~cm} \times 36 \mathrm{~cm})$ of each feedstock type were removed from the field within $24 \mathrm{~h}$ of harvesting. While larger rectangular bales are more economical for biomass logistics systems (Sokhansanj et al., 2009; Richard, 2010; Kemmerer and Liu, 2012), smaller bale sizes were used in the current study in order to serve as an initial assessment of the flow through high-density bales, while indicating the potential to remove the end-products of a biomass conversion process. Smaller bale sizes were also used in the current study to ensure uniform properties throughout the bulk material, while larger bale sizes would likely result in more variable characteristics throughout the bulk material. The bales were transported to the University of Kentucky research farm in Woodford County, Kentucky, where they were stored for a minimum of 50 days in a single layer in a well-ventilated barn. Following the storage period, the bales were transported to the Department of Biosystems and Agricultural Engineering at the University of Kentucky in Lexington, Kentucky, and were stored indoors in an air-conditioned laboratory. After storage, the bales were further compressed (fig. 1a) in the $z$-direction (fig. 1b) and all hydraulic properties were measured in the $y$-direction. Based on the bale weight and moisture 


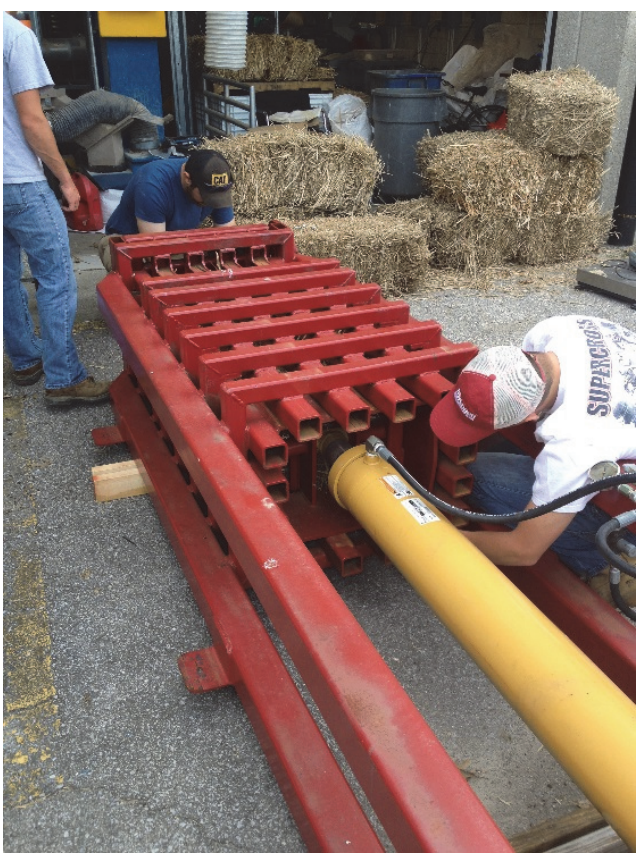

(a)

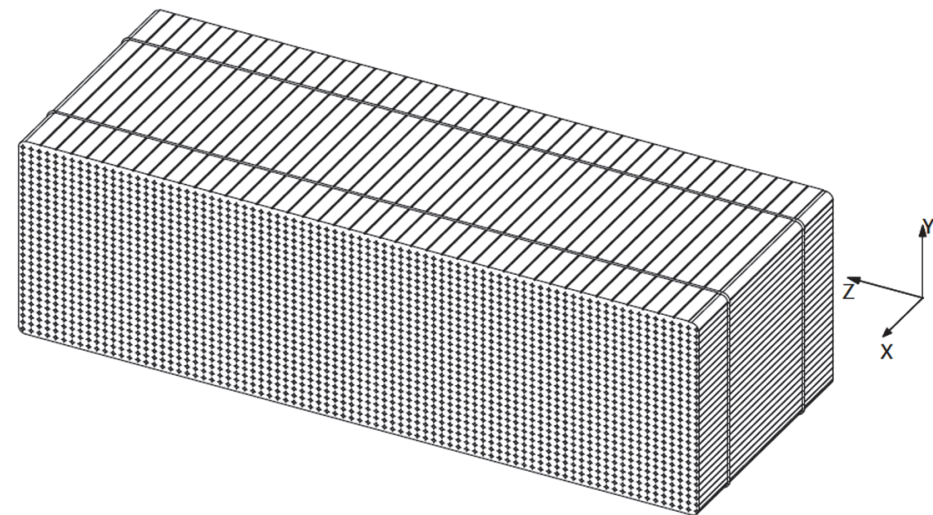

(b)

Figure 1. (a) Hydraulic recompression device for bales and (b) orientation of bales.

content, the bales were recompressed until the desired density was achieved. In this article, all bulk densities are expressed on a dry matter basis, and all moisture contents are expressed as percent wet basis (w.b.). Nominal dry matter bulk density levels of $150,175,200$, and $225 \mathrm{~kg} \mathrm{~m}^{-3}$ were targeted. These values are in the range reported for large rectangular bales of switchgrass (Sokhansanj et al., 2009) and alfalfa (Kemmerer and Liu, 2012).

Rough areas of each bale were trimmed to achieve relatively flat surfaces. Bale weight and dimensions were measured after trimming using a platform scale (Ohaus Corp., Parsippany, N.J.) and measuring tape (average of 12 individual bale measurements per rectangular dimension), respectively. Although the non-uniform packing of baled material may result in distinct layers of variable density throughout a bale, the apparent bale density is reported in this study by considering the bulk properties of each bale. The average moisture content of the bales was determined directly after the storage period but prior to the assessment of any hydraulic measurements. The moisture content was specifically determined from three replicate bales removed from the same storage operation. A $5.08 \mathrm{~cm}$ forage sampling probe with a serrated tip was used to collect the subsamples from each destructive bale replication according to the coring pattern presented by Smith et al. (2013). The average initial moisture content of each feedstock type was determined by ovendrying the subsamples at $103^{\circ} \mathrm{C} \pm 1^{\circ} \mathrm{C}$ for $24 \mathrm{~h}$, according to ASABE Standard S358.2 (ASABE, 2007). The initial and final mass of each subsample was measured with a weighing scale and used to calculate the average moisture content of the bales following the storage period.

\section{Saturated Conditions}

Initial maximum moisture content and leaching characteristics were first assessed by fully submerging 12 bales of each feedstock (three replications per density level) in a water bath for approximately $15 \mathrm{~min}$ to ensure initial saturation. The fully saturated bales were then placed on a platform scale in an air-conditioned laboratory (approx. $22^{\circ} \mathrm{C}$ ) to permit excess water to drain from the material in the $y$-direction (fig. 1b). The weight of each bale was monitored for $60 \mathrm{~h}$, when the bales approached an equilibrium weight. Each bale was monitored asynchronously during this experiment using the same platform scale for each treatment and replication. Three samples were then collected from each bale using a 2 in. $(5 \mathrm{~cm})$ diameter bale probe and were stored at $-9^{\circ} \mathrm{C}$ for several days. The coring pattern included low $(\sim 13 \mathrm{~cm}$ ( $\sim 5$ in.) above the bottom surface), central (centered with the height), and upper ( $\sim 13 \mathrm{~cm}(\sim 5 \mathrm{in}$.) below the top surface) positions in each bale. Each sample was cored to the center of each respective bale at a depth of approximately $23 \mathrm{~cm}$ (9.0 in.) to allow uniform measurements across all treatments while accounting for any potential variation, which could occur in one or more of the principle directions. After $60 \mathrm{~h}$ of leaching, minimal differences in moisture content were observed between the three sampling positions within each bale. After thawing to room temperature, the samples were weighed, placed in paper bags, and oven-dried at $103^{\circ} \mathrm{C} \pm 1^{\circ} \mathrm{C}$ for $24 \mathrm{~h}$. The initial and final mass of each sample was then measured with a weighing scale and correlated to the moisture content of each bale during leaching as a function of the density and feedstock type.

The saturated hydraulic conductivity was determined for each feedstock type using a constant head technique with the flow direction perpendicular to the consolidation direction (y-direction shown in fig. 1b). Each bale was first fitted within a plywood frame leaving the top and bottom of the bale exposed. Spray insulation foam (Great Stuff, Dow Chemicals) was then applied between the wooden frame and the vertical surfaces of each bale to ensure a watertight seal, 
as shown in figures $2 \mathrm{a}, 2 \mathrm{~b}$, and $2 \mathrm{c}$. The spray foam effectively prevented boundary flow and allowed the assumption of one-dimensional flow through each bale from top to bottom. An aluminum box with outlets at varying heights to provide a constant head was firmly secured to the wooden box with the bale using ratchet straps (fig. 2d).

Water was supplied to the experimental setup from a $1050 \mathrm{~L}$ ( $275 \mathrm{gal}$ ) polyethylene reservoir located above the aluminum head control box that was attached to the wooden bale frame, as shown in figure 3. Spacers in the bottom of the catch basin allowed unrestricted flow through the bale. Constant head was maintained by allowing excess water to drain from the head control box away from the catch basin. Thus, a fixed hydraulic gradient was established through the cross-sectional area of the bale. Steady-state flow conditions were confirmed by constant flow readings in order to ensure that the bales were fully saturated. Tests were conducted at

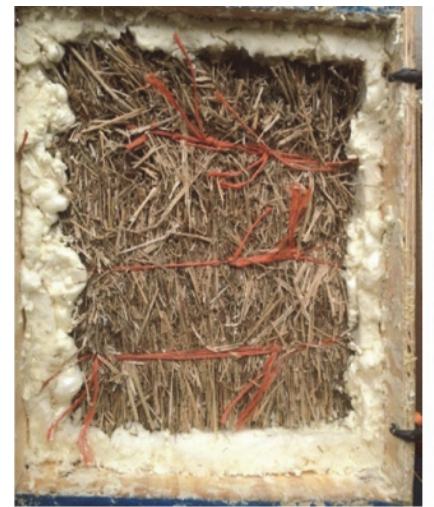

(a)

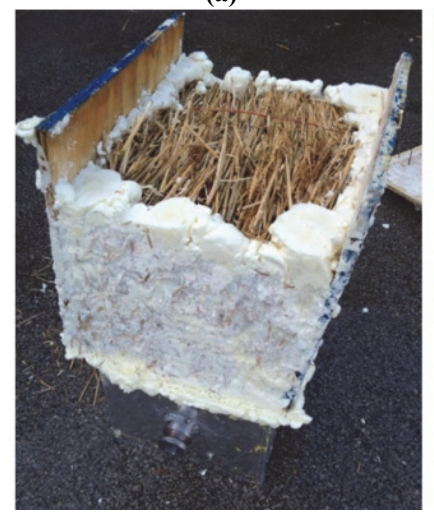

(c)

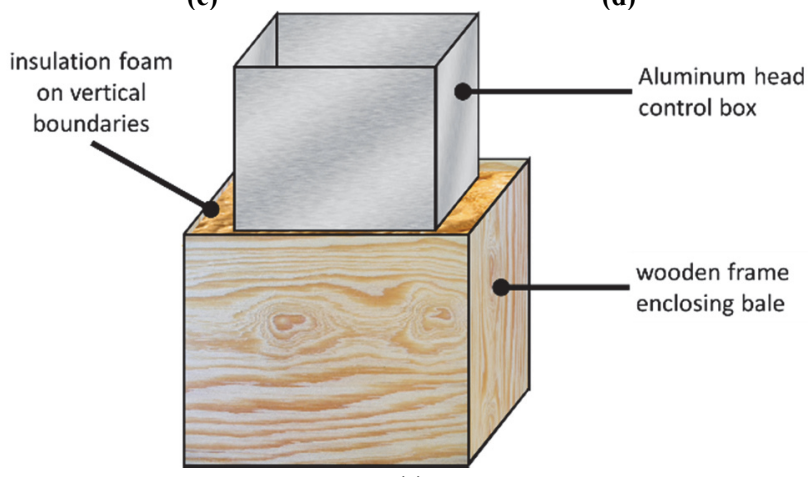

(e)

Figure 2. (a, b, c) Bale fitted into plywood frame with spray insulation foam preventing boundary flow, (d) head control box on top of frame, and (e) diagram of experimental setup. three head levels for each bale $(50.8 \pm 2.3 \mathrm{~cm}, 57.9 \pm 2.5 \mathrm{~cm}$, and $68.3 \pm 2.8 \mathrm{~cm})$. The volume of water flowing through each bale was determined by collecting and weighing the runoff water from the outflow catchment over a specified time period, typically between 30 to $90 \mathrm{~s}$ depending on the flow rate. Triplicate readings were taken to ensure constant flow within $\pm 50.0 \mathrm{~g}$, which corresponded to $\pm 209.8 \mathrm{~cm}^{3}$ based on the density of water. The saturated hydraulic conductivity of each bale was then determined by Darcy's law, which describes the relationship between flow rate and head loss through a saturated porous medium as follows:

$$
K_{s}=\frac{Q}{A} \frac{L}{H}
$$

where $K_{\mathrm{s}}$ is the saturated hydraulic conductivity of the porous medium $\left(\mathrm{cm} \mathrm{s}^{-1}\right), Q$ is the flow rate through the medium $\left(\mathrm{cm}^{3} \mathrm{~s}^{-1}\right), A$ is the cross-sectional area of the bale perpendicular to the direction of flow $\left(\mathrm{cm}^{2}\right)$, and $H / L$ is the potential gradient or head loss per unit length $\left(\mathrm{cm} \mathrm{cm}^{-1}\right)$.

Darcy's law assumes laminar flow through the material, while turbulent flow, which is associated with higher flow rates, results in nonlinear behavior. Each density level was assessed in triplicate, for a total of 12 observations for each feedstock type (three replications per density level). All data were analyzed by the GLM procedure using SAS (SAS Institute, Cary, N.C.) with bale density and feedstock type treated as fixed effects. The pairwise t-test was used for means comparison with a 0.05 statistical significance.

\section{UNSATURATED CONDITIONS}

Water retention under unsaturated conditions within baled switchgrass was determined by the filter paper method at three target dry matter density levels $(175,200$, and $225 \mathrm{~kg} \mathrm{~m}^{-3}$ ). This analysis was accomplished through the use of a water characteristic curve (WCC) according to ASTM Standard D5298 for soil samples (ASTM, 1992). Filter paper tests are highly sensitive suction measurements that generally require a high degree of controlled protocol in order to attain accurate results. Thus, care was exercised in performing these experiments, which were assumed to provide sufficient estimates of the matric suction within baled biomass. Accordingly, bales were prepared at target moisture levels ranging from $10 \%$ to $40 \%$ (w.b.) in increments of $5 \%$ (w.b.).

Individual filter papers (Whatman No. 42) were prepared by oven-drying overnight ( $16 \mathrm{~h}$ ), cutting, and then sandwiching between two larger $(5.5 \mathrm{~cm}$ diameter) protective filter papers. The sandwiched filter papers were inserted into three locations between the flakes of each bale while ensuring good contact with the biomass material. Hence, matric suction was measured because the flow of liquid water was expected to contribute significantly to the establishment of equilibrium conditions, particularly at higher moisture levels. The bales were wrapped in impermeable plastic to prevent water exchange with the environment and stored in the lab for ten days. Thus, the filter paper was allowed to equilibrate with the porous material through liquid flow (matric suction) while held at a relative constant temperature in the lab $\left(21.7^{\circ} \mathrm{C} \pm 0.4^{\circ} \mathrm{C}\right)$. The filter papers were carefully extracted after equilibrium was established, and the water con- 


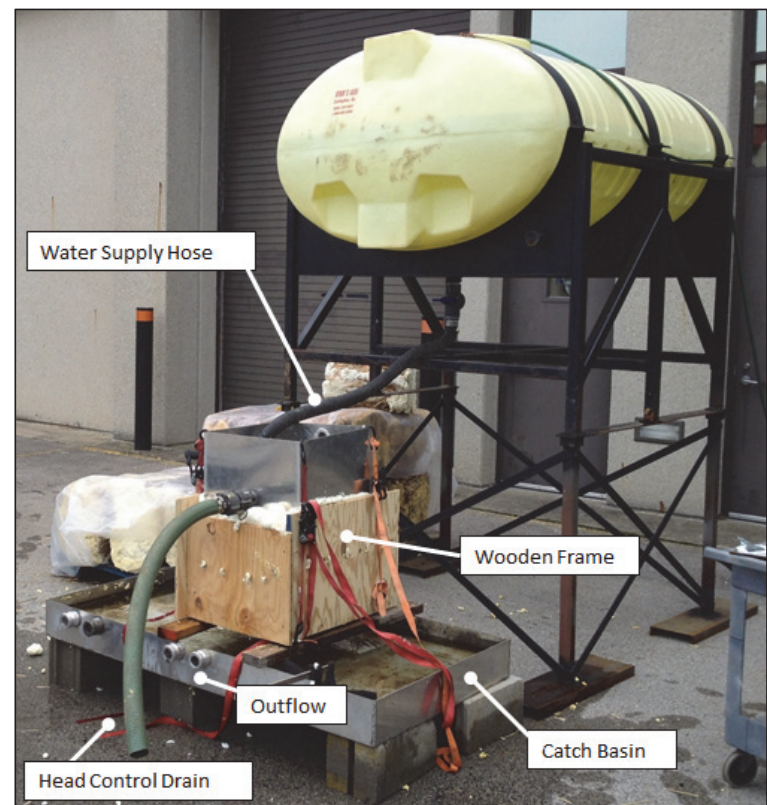

(a)

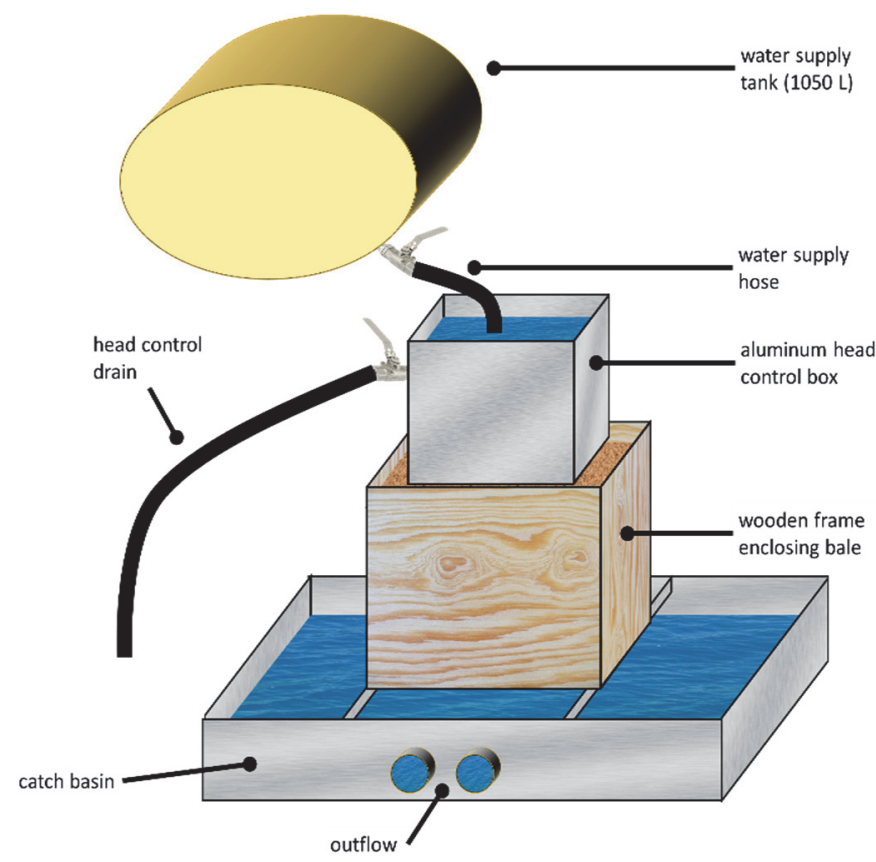

(b)

Figure 3. (a) Constant head apparatus with a reservoir supplying water to the aluminum head control box, which is positioned on top of the framed bale, and (b) a diagram of the constant head apparatus.

tent of each filter paper was then measured by standard gravimetric analysis.

The corresponding matric suction values were identified using a WCC (ASTM, 1992) and subsequently plotted against the average moisture content of three replicate samples from the corresponding region within each bale. Inverse modeling of the van Genuchten model was then carried out with a computational solver (Seki, 2007) to provide optimized values of the water content and pressure head data using the least squares method. The van Genuchten equation is expressed as:

$$
\theta_{e}=\frac{\theta-\theta_{s}}{\theta_{s}-\theta_{r}}=\left[\frac{1}{1+(\alpha h)^{n}}\right]^{m}
$$

where $\theta_{e}$ is the effective water content $(\%), \theta$ is the water content $(\%), \theta_{s}$ is the saturation moisture $(\%), \theta_{r}$ is the residual moisture $(\%), h$ is the pressure head $(\mathrm{cm}), \alpha$ is an empirical parameter $\left(\mathrm{cm}^{-1}\right), n$ is an empirical parameter, and $m=$ $1-1 / n$.

Infiltration tests were then performed on baled switchgrass by modifying the experimental methods described by Hillel (1998). For each density level, a $3.1 \mathrm{~cm}$ diameter infiltrometer (Mini Disk v9, Decagon Devices, Inc., Pullman, Wash.) was used to infiltrate water into bales at a tension of $-2 \mathrm{~cm}$ of water. The treatments consisted of three target dry matter densities $\left(175,200\right.$, and $\left.225 \mathrm{~kg} \mathrm{~m}^{-3}\right)$ and four target moisture levels $(10 \%, 20 \%, 30 \%$, and $40 \%$ w.b.). Replicate infiltration tests were performed at three locations on each bale, while each treatment was performed with triplicate bales, for a total of 108 observations (12 treatments $\times 3$ locations $\times 3$ replications). A $5.1 \mathrm{~cm}$ steel feedstock probe with a serrated tip was carefully drilled through each bale with minimal disturbance to the material, as shown in figure 4. A thin layer $(5 \mathrm{~mm})$ of fine silica sand was applied at each measurement location to smooth out surface irregularities and to ensure good contact with the infiltrometer membrane. The volume of water $(I)$ and infiltration time $(t)$ were recorded at regular intervals $(30 \mathrm{~s})$ during infiltration. Philip's two-term equation (Philip, 1957) was then applied to the cumulative infiltration data as follows:

$$
I(t)=C_{1} t+C_{2} \sqrt{t}
$$

where $I(t)$ is the cumulative infiltration $(\mathrm{mL}), t$ is the time (s), $C_{1}$ is the hydraulic conductivity $\left(\mathrm{cm} \mathrm{s}^{-1}\right)$, and $C_{2}$ is the sorptivity coefficient $\left(\mathrm{cm} \mathrm{s}^{-1 / 2}\right)$. This model assumes steadystate water flow, constant water content within the transport volume, and minimum lateral mixing.

The Mualem hydraulic parameters, unsaturated hydraulic conductivity $\left(K_{u}\right)$ and sorptivity $(S)$, were then estimated for baled switchgrass as a function of density using the inverse modeling approach with the fitted values of $C_{1}$ and $C_{2}$ according to the following equations:

$$
\begin{gathered}
K_{u}(\theta, h)=\frac{C_{1}}{A_{1}} \\
S(\theta, h)=\frac{C_{2}}{A_{2}}
\end{gathered}
$$

where $A_{1}$ and $A_{2}$ are dimensionless coefficients estimated by equations 6,7 , and 8 (Zhang, 1997):

$$
A_{1}=\frac{11.65\left(n^{0.1}-1\right) \exp \left[2.92(n-1.9) \alpha h_{o}\right]}{\left(\alpha r_{o}\right)^{0.91}}, n \geq 1.9
$$



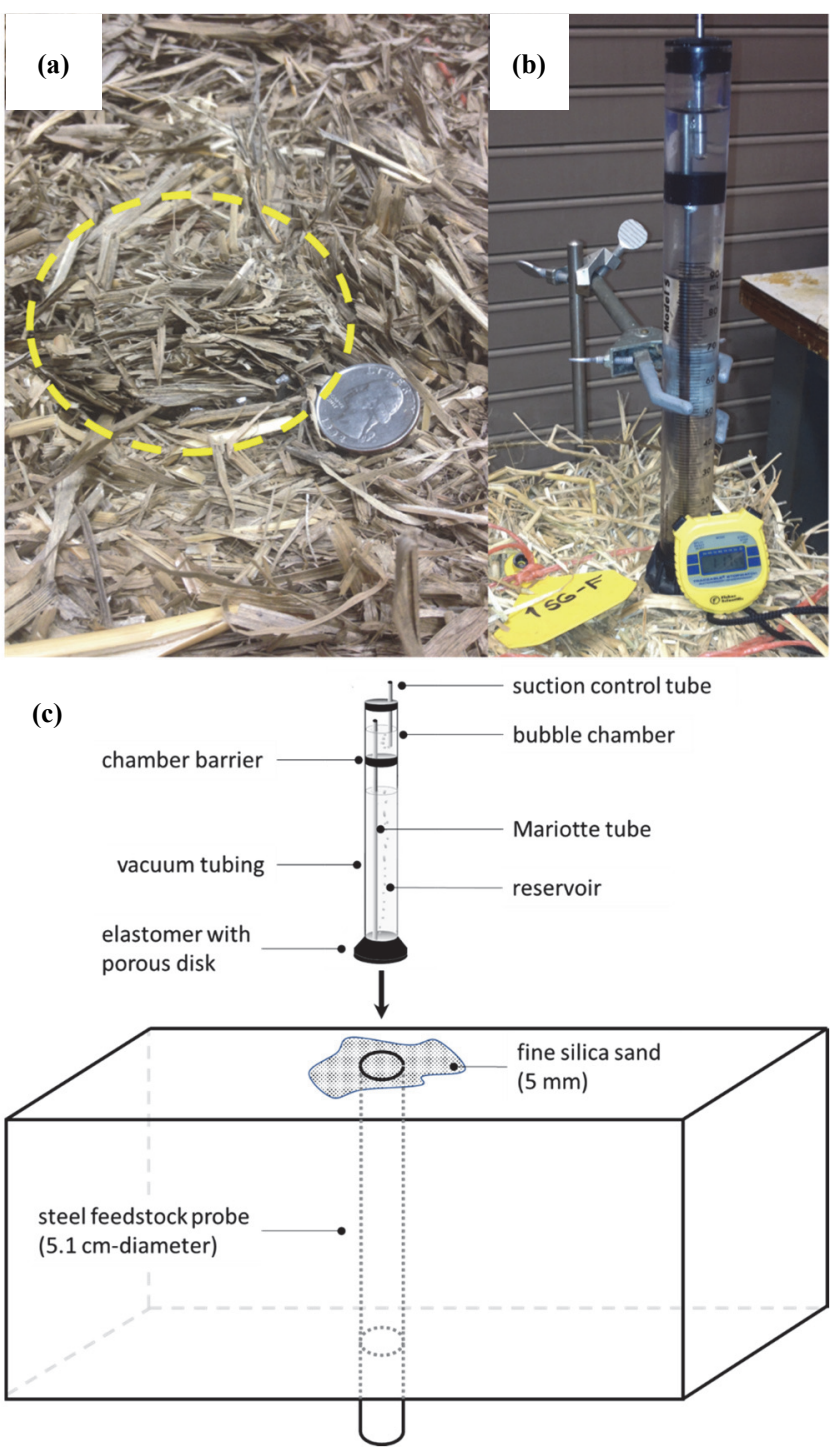

Figure 4. (a) The $5.1 \mathrm{~cm}$ diameter probe was inserted into baled switchgrass to limit lateral flow while causing minimal disruption of the material, (b) the infiltrometer positioned on the surface of the bale, and (c) a diagram of the infiltrometer positioned over the feedstock probe, which has been inserted into a small rectangular bale.

$$
\begin{gathered}
A_{1}=\frac{11.65\left(n^{0.1}-1\right) \exp \left[7.5(n-1.9) \alpha h_{o}\right]}{\left(\alpha r_{o}\right)^{0.91}}, n<1.9 \\
A_{2}=\frac{1.4 b^{0.5}\left(\theta_{o}-\theta_{i}\right)^{0.25} \exp \left[3(n-1.9) \alpha h_{o}\right]}{\left(\alpha r_{o}\right)^{0.15}}
\end{gathered}
$$

where $r_{o}$ is the ring diameter $(\mathrm{cm}), b=0.55$ (Warrick et al., 1992), $h_{o}$ is the suction (tension, $h<0$ ) at the disk surface $(-2 \mathrm{~cm}), \theta_{o}$ is the water content at $h_{o}(\%), \theta_{i}$ is the initial water content (\%), and $n$ and $\alpha$ are the van Genuchten parameters calculated using equation 2 .

The data were analyzed by the GLM procedure (SAS Institute, Cary, N.C.) with bale density treated as a fixed effect $(\alpha=0.05)$.

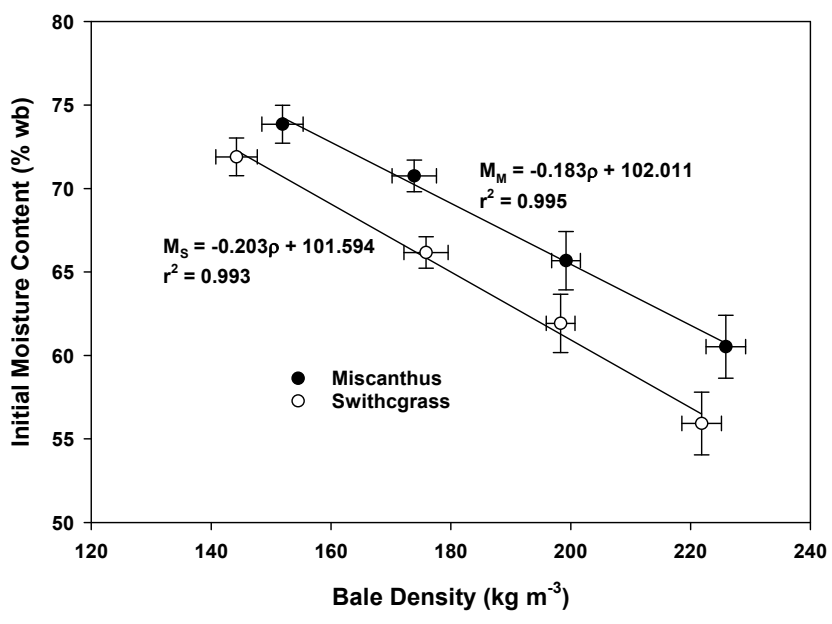

Figure 5. Initial moisture content of baled switchgrass $\left(M_{S}\right)$ and miscanthus $\left(M_{M}\right)$ as a function of dry bale density with linear regression coefficients $\left(R^{2}\right)$ of 0.99 for both feedstocks.

\section{RESULTS AND DISCUSSION}

The average moisture content of the starting material was $10.9 \% \pm 0.3 \%$ w.b. for switchgrass and $9.6 \% \pm 0.3 \%$ w.b. for miscanthus. The moisture levels were low and uniform due to extended storage within a climate-controlled laboratory.

\section{SATURATEd RESUlts}

The average saturated moisture contents of both feedstock types are plotted in figure 5 as a function of dry bale density. Based on preliminary tests, accurate measurements were unattainable at bale densities below $150 \mathrm{~kg} \mathrm{~m}^{-3}$ due to rapid leaching. However, the elevated density levels presented here are preferable for minimizing transportation costs. The average saturated moisture content ranged between $56 \%$ and $72 \%$ (w.b.) for switchgrass and between $61 \%$ and $74 \%$ (w.b.) for miscanthus, depending on the bale density. However, no significant differences $(p=0.218)$ were observed between the saturated moisture content of switchgrass and miscanthus at a 5\% significance level. Linear models were applied to both feedstock types in order to describe the inverse correlation between saturated moisture content and bale density as follows:

$$
\begin{aligned}
& M_{S}=101.594-0.203 \rho \\
& M_{M}=102.011-0.183 \rho
\end{aligned}
$$

where $\rho$ is the dry bale density $\left(\mathrm{kg} \mathrm{m}^{-3}\right)$, and $M_{S}$ and $M_{M}$ are the saturated moisture contents ( $\%$ w.b.) for switchgrass and miscanthus, respectively.

The corresponding $\mathrm{R}^{2}$ regression coefficients were 0.99 for both feedstocks. This inversely correlated trend between saturated moisture content and bale density $(p<0.01)$ was primarily due to water entrapment in the void spaces. The larger and more extensive void spaces associated with lowerdensity bales allowed increased water storage. Likewise, it is believed that the miscanthus bales offered increased void space for water to fill, thereby increasing the saturated moisture content at all density levels. However, no significant differences $(p=0.218)$ were observed between the saturated 
moisture contents of switchgrass and miscanthus at a 5\% significance level.

The average leaching behavior of saturated bales over approximately $60 \mathrm{~h}$ is shown in figure 6 . Each curve represents the average of three replicate bales. Rapid leaching of water was observed within the first $0.1 \mathrm{~h}$, with average reductions in moisture content of 7.3 and 7.0 percentage points (w.b.) for switchgrass and miscanthus, respectively. In general, larger reductions in moisture content were observed in the lower-density bales. For example, miscanthus bales with a density of $150 \mathrm{~kg} \mathrm{~m}^{-3}$ had an initial saturated moisture content of $73.9 \%$ (w.b.), which decreased to $64.9 \%$ (w.b.) within $0.08 \mathrm{~h}$, while miscanthus bales with a density of $225 \mathrm{~kg} \mathrm{~m}^{-3}$ decreased from $60.5 \%$ to $55.8 \%$ (w.b.) within 0.08 h. After the rapid leaching phase, small reductions in saturated moisture content occurred over the remainder of the $60 \mathrm{~h}$ period. From 0.3 to $60 \mathrm{~h}$, the moisture content decreased by an average of 4.3 and 4.4 percentage points in the miscanthus and switchgrass bales, respectively. Based on these results, the density and feedstock type interactions were both significant at $\alpha=0.05(\mathrm{p}<0.01)$.

The hydraulic flux $(Q / A)$ was plotted as a function of the

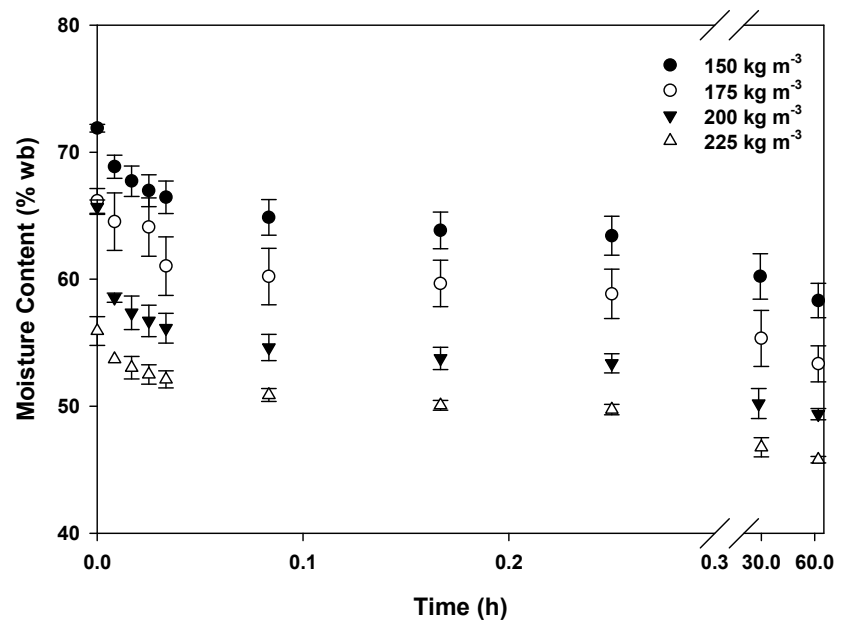

(a) hydraulic gradient $(H / L)$ for both feedstock types, as shown in figure 7, with respect to the density level. Preliminary trials indicated that density levels below $150 \mathrm{~kg} \mathrm{~m}^{-3}$ (d.b.) resulted in turbulent flow, which violated the assumption of Darcy's law. Thus, the effect of bale density for values below $150 \mathrm{~kg} \mathrm{~m}^{-3}$ (d.b.) could not be accurately determined due to rapid flow rates. However, each data set presented here represents the average of three replicate observations (bales) for both feedstock types assessed at three hydraulic gradients. The saturated hydraulic conductivity was then determined for each data set by linear regression to determine the slope (saturated hydraulic conductivity), which was fit to the experimental data (forced through zero).

The estimates of hydraulic conductivity are summarized in table 1 based on the linear regression models for both feedstock types. The average saturated hydraulic conductivity ranged between 0.103 and $0.616 \mathrm{~cm} \mathrm{~s}^{-1}$ for baled switchgrass and between 0.219 and $0.658 \mathrm{~cm} \mathrm{~s}^{-1}$ for baled miscanthus, depending on the density. As expected, these results are slightly lower than the values reported for various wood media, which ranged between $2.4 \pm 2.0 \mathrm{~cm} \mathrm{~s}^{-1}$ and $11.01 \pm 3.0 \mathrm{~cm} \mathrm{~s}^{-1}$ (Robertson et al., 2005; Van Driel et al.,

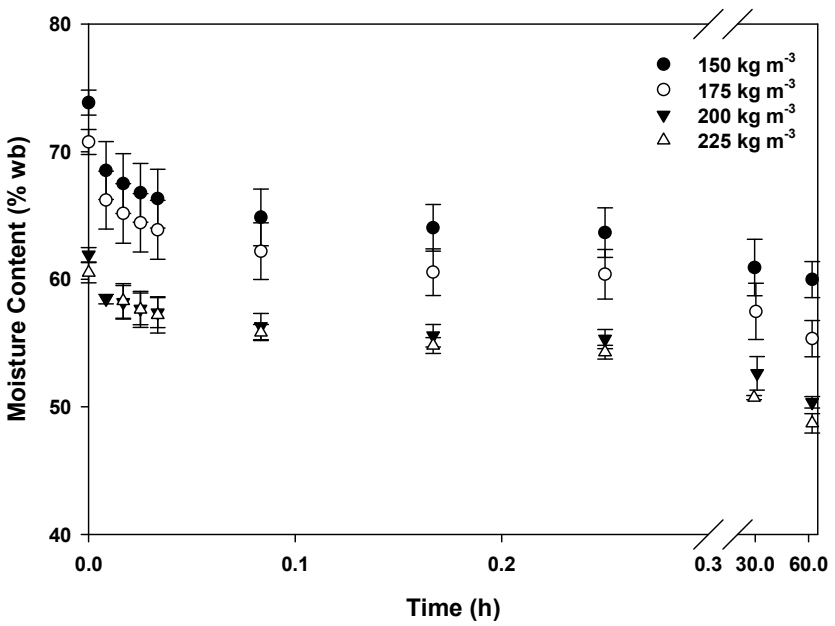

(b)

Figure 6. Leaching curves for fully saturated (a) miscanthus and (b) switchgrass bales at dry matter densities of $150,175,200$, and $225 \mathrm{~kg} \mathrm{~m}^{-3}$.

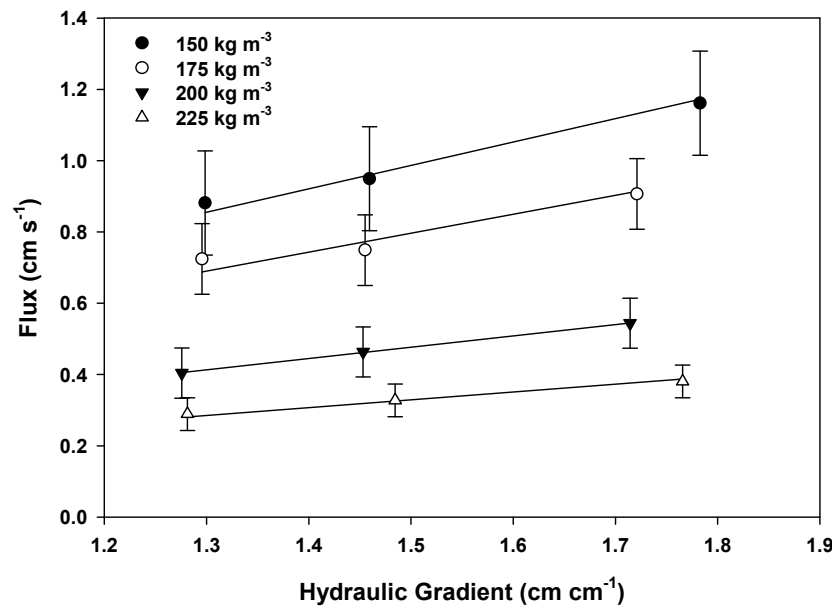

(a)

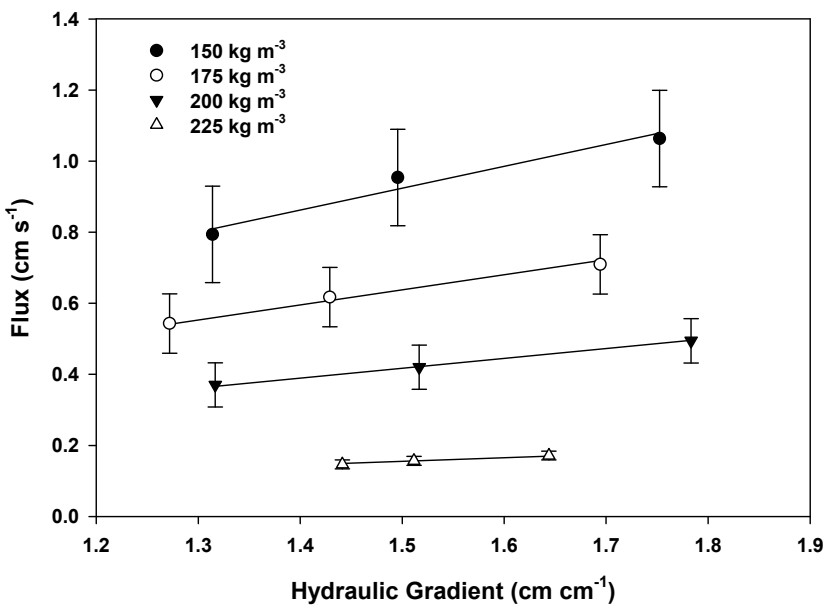

(b)

Figure 7. Hydraulic flux and standard deviation versus hydraulic gradient of baled (a) miscanthus and (b) switchgrass at target densities of 150, 175,200 , and $225 \mathrm{~kg} \mathrm{DM} \mathrm{m}^{-3}$ with linear regression lines. 
Table 1. Mean values of saturated hydraulic conductivity $\left(K_{s}\right)$ for miscanthus and switchgrass at four apparent dry matter bale densities with linear regression coefficients $\left(\mathrm{R}^{2}\right)$ and standard errors (SE).

\begin{tabular}{|c|c|c|c|c|c|c|c|}
\hline \multirow[b]{2}{*}{$\begin{array}{l}\text { Density } \\
\left(\mathrm{kg} \mathrm{m}^{-3}\right)\end{array}$} & \multirow[b]{2}{*}{$\begin{array}{c}\mathrm{SE} \\
\left(\mathrm{kg} \mathrm{m}^{-3}\right)\end{array}$} & \multicolumn{3}{|c|}{ Miscanthus } & \multicolumn{3}{|c|}{ Switchgrass } \\
\hline & & $\begin{array}{c}K_{s} \\
\left(\mathrm{~cm} \mathrm{~s}^{-1}\right)\end{array}$ & $\begin{array}{c}\mathrm{SE} \\
\left(\mathrm{cm} \mathrm{s}^{-1}\right)\end{array}$ & $\mathrm{R}^{2}$ & $\begin{array}{c}K_{s} \\
\left(\mathrm{~cm} \mathrm{~s}^{-1}\right)\end{array}$ & $\begin{array}{c}\mathrm{SE} \\
\left(\mathrm{cm} \mathrm{s}^{-1}\right)\end{array}$ & $\mathrm{R}^{2}$ \\
\hline 144.2 & 6.7 & 0.658 & 0.146 & 0.98 & 0.616 & 0.136 & 0.96 \\
\hline 173.0 & 4.4 & 0.531 & 0.099 & 0.90 & 0.425 & 0.084 & 0.98 \\
\hline 201.8 & 3.8 & 0.318 & 0.070 & 0.99 & 0.278 & 0.062 & 0.99 \\
\hline 225.9 & 3.4 & 0.219 & 0.046 & 0.97 & 0.103 & 0.012 & 0.98 \\
\hline
\end{tabular}

2006; Chun et al., 2009), but are elevated compared with that of alfalfa silage $\left(0.002 \mathrm{~cm} \mathrm{~s}^{-1}\right)$ with a dry density of approximately $216 \mathrm{~kg} \mathrm{~m}^{-3}$ (Yao and Jofriet, 1992), chopped sorghum (between 0.001 to $1 \mathrm{~cm} \mathrm{~s}^{-1}$ ) (Custer et al., 1990), and for wood chip media $\left(9.5 \mathrm{~cm} \mathrm{~s}^{-1}\right)$ in denitrifying bioreactors (Christianson et al., 2010). These differences are attributed to the bale properties (porosity, tortuosity, and particle orientation) and density differences.

Results indicated that the saturated hydraulic conductivity $\left(K_{s}\right)$ was strongly influenced by the apparent bale density $(\mathrm{p}<$ $0.02)$. In fact, the $K_{s}$ values at the lowest target dry matter density $\left(150 \mathrm{~kg} \mathrm{~m}^{-3}\right)$ were only $16.7 \%$ and $33.3 \%$ of the values recorded at the highest target dry matter density $\left(225 \mathrm{~kg} \mathrm{~m}^{-3}\right)$ for switchgrass and miscanthus, respectively. Furthermore, the feedstock type effects were found to be minimal, particularly at the lower bale densities, while a significant feedstock type effect $(\mathrm{p}<0.0001)$ was observed at the highest target dry matter density $\left(225 \mathrm{~kg} \mathrm{~m}^{-3}\right)$. Linear models were fitted to the conductivity data, which was inversely related to bale density, a scenario that was valid for most soils (Lambe and Whitman, 1969). The two best-fit models are:

$$
\begin{gathered}
K_{S(S)}=1.5728-0.0066 \rho \\
K_{S(M)}=1.5898-0.0062 \rho
\end{gathered}
$$

where $K_{S(S)}$ and $K_{S(M)}$ are the saturated hydraulic conductivities for switchgrass and miscanthus $\left(\mathrm{cm} \mathrm{s}^{-1}\right)$, respectively, and $\rho$ is the apparent dry bale density $\left(\mathrm{kg} \mathrm{m}^{-3}\right)$. These prediction equations for density-dependent hydraulic conductivity were found to fit the data very well, with $\mathrm{R}^{2}$ values of 0.99 and 0.97 for switchgrass and miscanthus, respectively. The standard deviations of the two feedstock types were ob-

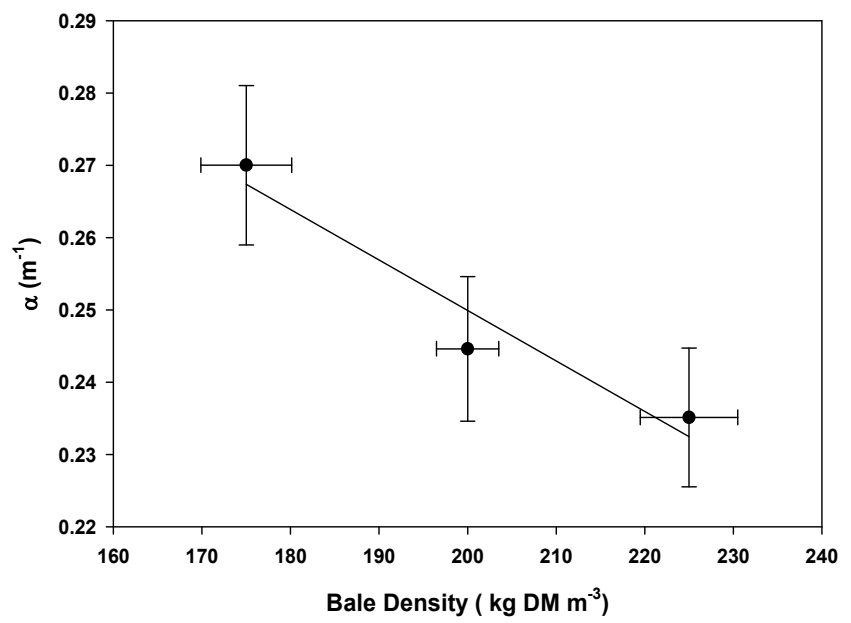

served to overlap, although the hydraulic conductivity was statistically lower $(p<0.01)$ for switchgrass bales than for miscanthus bales at the highest dry matter bulk density $\left(225 \mathrm{~kg} \mathrm{~m}^{-3}\right)$.

\section{UNSATURATED RESULTS}

The matric suction of baled switchgrass, resulting from the filter paper tests, is plotted versus volumetric water content in figure 8, along with the water retention curves developed by inverse modeling of the van Genuchten procedure. Results showed a satisfactory agreement between the van Genuchten model and experimental data at each density. The van Genuchten parameters ( $\alpha$ and $n$ ) are plotted as functions of bale density in figure 9 . Each data set represents the aver-

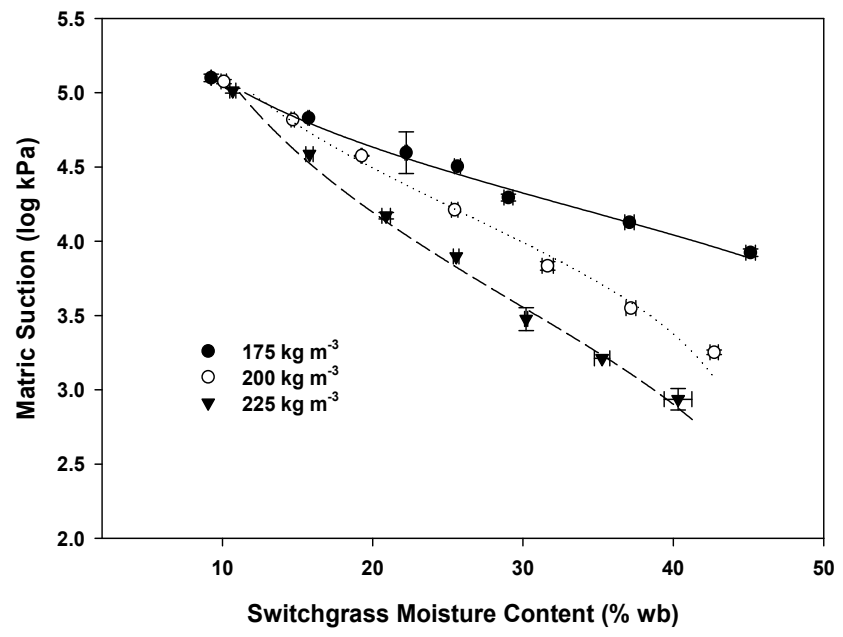

Figure 8. Measured matric suction values versus volumetric water content for baled switchgrass at target densities of 175,200 , and $225 \mathrm{~kg}$ $\mathrm{m}^{-3}$. Lines are water retention curves developed by inverse modeling of the van Genuchten procedure.

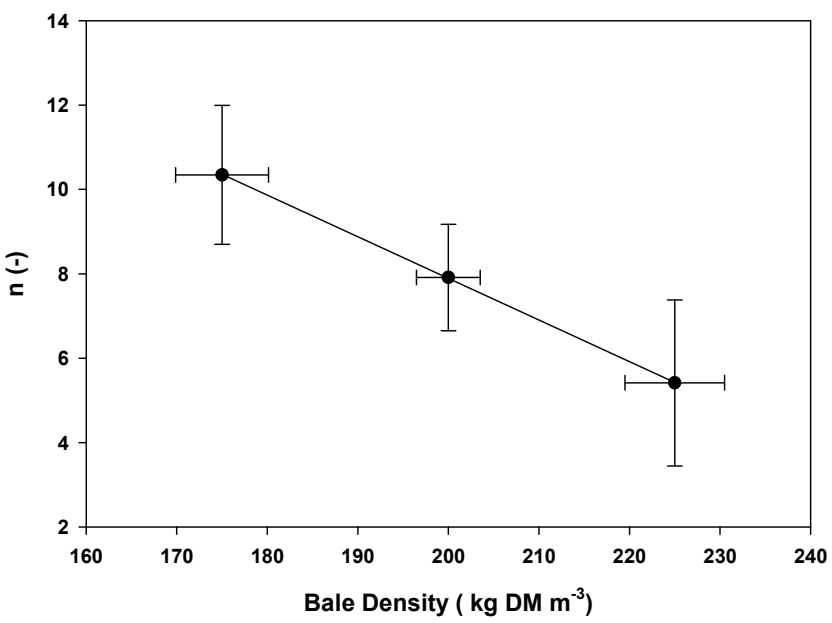

Figure 9. The van Genuchten parameters ( $\alpha$ and $n$ ) of baled switchgrass plotted as functions of dry matter density. Error bars are standard errors of three replicates. 
age of three replicate observations (bales), which are described by linear trendlines with regression coefficients of 0.93 and 0.99 for $\alpha$ and $n$, respectively. These results indicate a significant correlation with bulk density $(\mathrm{p}<0.05)$.

Table 2 summarizes the average values and standard errors of hydraulic conductivity $\left(C_{1}\right)$ and sorptivity $\left(C_{2}\right)$ as functions of bale density for Philip's two-term equation for infiltration. Each data point represents the average of three replicate bales, as determined from the cumulative infiltration data. The average values of $C_{1}$ and $C_{2}$ ranged between 0.086 and $0.779 \mathrm{~cm} \mathrm{~s}^{-1}$ and between 0.200 and $5.805 \mathrm{~cm}$ $\mathrm{s}^{-1 / 2}$, respectively, depending on the bale density and moisture content. The standard errors of $C_{1}$ and $C_{2}$ were minimal, with averages of only $\pm 0.5 \%$ and $\pm 1.0 \%$ of the reported values, respectively. A two-way analysis of variance indicated that bale moisture $(\mathrm{p}<0.01)$ and density $(\mathrm{p}<0.02)$ significantly affected the hydraulic parameters. These results are greater than those reported for soil (Zhang, 1997), which was expected due to the larger pore space in baled switchgrass.

The hydraulic conductivity and sorptivity of baled switchgrass, as estimated from the cumulative infiltration data, are summarized in table 3 . The average unsaturated conductivity $\left(K_{u}\right)$ ranged between 0.019 and $0.272 \mathrm{~cm} \mathrm{~s}^{-1}$ depending on the bale density and moisture content. The calculated $K_{u}$ values were higher than for other materials such as soil, for which typical $K_{u}$ values were between $3.32 \times$ $10^{-6}$ and $6.79 \times 10^{-6} \mathrm{~m} \mathrm{~s}^{-1}$ (Zhang, 1997). As expected, the $K_{u}$ values for baled switchgrass were higher, likely due to the increased pore space and corresponding higher water flow rate through the material. Likewise, these results are consistent with the saturated values reported earlier in this study, which were higher due to the fully saturated, steady-state flow conditions. Thus, the unsaturated $K_{u}$ values developed for baled switchgrass may be considered appropriate for use in unsaturated flow calculations.

A two-way analysis of variance indicated that bale density $(\mathrm{p}<0.01)$ and moisture content $(\mathrm{p}<0.02)$ significantly affected both the unsaturated hydraulic conductivity and the sorptivity. The inverse relationship between the hydraulic parameters and bale density is associated with the void and interparticle space in which fluid flow occurs. Accordingly, the higher-density bales had less interparticle space, thereby inhibiting fluid flow. This effect was reversed in the lowerdensity bales because the large void space permitted greater fluid flow through the bales. Initially, the moisture content was observed to inhibit the flow of water through the material, thereby resulting in lower $K_{u}$ values. This is expected to be a result of various adhesive forces between the water and surfaces of the switchgrass. Additional fluid must either overcome these surface forces or be redirected into new pore channels. This effect is at least minimized at saturated conditions in which steady-state flow is established through all pore channels. For most cases, the standard errors were within $1 \%$, while the maximum standard error was $1.6 \%$. In general, the computation of $K_{u}$ is more sensitive to moisture content, and less sensitive to density, than the computation of $S$.

\section{CONCLUSION}

A methodology was proposed in this study for estimating the hydraulic properties within baled feedstocks with initial saturated moisture contents ranging between $55.9 \%$ and $71.9 \%$ (w.b.) for switchgrass and between $60.5 \%$ and $73.9 \%$ (w.b.) for miscanthus, depending on the bale density. The inverse relationship between saturated moisture content and bale density was governed by the potential water entrapment within the available void space of each bale. Rapid leaching of water from saturated bales was observed within the first $0.1 \mathrm{~h}$, with average reductions in moisture content of 7.3 and 7.0 percentage points (w.b.) for switchgrass and miscanthus, respectively.

Saturated hydraulic conductivity was also evaluated using a constant head system, with the values at the lowest target dry matter density $\left(150 \mathrm{~kg} \mathrm{~m}^{-3}\right)$ representing only $16.7 \%$ and $33.3 \%$ of the values recorded at the highest dry bale density $\left(225 \mathrm{~kg} \mathrm{~m}^{-3}\right)$ for switchgrass and miscanthus, respectively. This inverse relationship between hydraulic conductivity and bale density is associated with the reduced void and interparticle space in higher-density bales, which inhib-

Table 2. Average values of curve-fitting parameters $C_{1}$ and $C_{2}$ of Philip's two-term equation for baled switchgrass as functions of dry matter

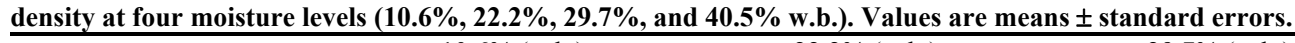

\begin{tabular}{|c|c|c|c|c|c|c|c|c|c|}
\hline \multirow[b]{2}{*}{$\begin{array}{l}\text { Density } \\
\left(\mathrm{kg} \mathrm{m}^{-3}\right)\end{array}$} & \multirow[b]{2}{*}{$\begin{array}{c}\mathrm{SE} \\
\left(\mathrm{kg} \mathrm{m}^{-3}\right)\end{array}$} & \multicolumn{2}{|c|}{$10.6 \%$ (w.b.) } & \multicolumn{2}{|c|}{$22.2 \%$ (w.b.) } & \multicolumn{2}{|c|}{$29.7 \%$ (w.b.) } & \multicolumn{2}{|c|}{$40.5 \%$ (w.b.) } \\
\hline & & $\begin{array}{c}C_{1} \\
\left(\mathrm{~cm} \mathrm{~s}^{-1}\right)\end{array}$ & $\begin{array}{c}C_{2} \\
\left(\mathrm{~cm} \mathrm{~s}^{-1 / 2}\right)\end{array}$ & $\begin{array}{c}C_{1} \\
\left(\mathrm{~cm} \mathrm{~s}^{-1}\right)\end{array}$ & $\begin{array}{c}C_{2} \\
\left(\mathrm{~cm} \mathrm{~s}^{-1 / 2}\right)\end{array}$ & $\begin{array}{c}C_{1} \\
\left(\mathrm{~cm} \mathrm{~s}^{-1}\right)\end{array}$ & $\begin{array}{c}C_{2} \\
\left(\mathrm{~cm} \mathrm{~s}^{-1 / 2}\right)\end{array}$ & $\begin{array}{c}C_{1} \\
\left(\mathrm{~cm} \mathrm{~s}^{-1}\right)\end{array}$ & $\begin{array}{c}C_{2} \\
\left(\mathrm{~cm} \mathrm{~s}^{-1 / 2}\right)\end{array}$ \\
\hline 174.1 & 1.9 & 0.779 & 5.805 & 0.725 & 4.948 & 0.539 & 2.958 & 0.299 & 1.601 \\
\hline & & \pm 0.003 & \pm 0.009 & \pm 0.004 & \pm 0.038 & \pm 0.003 & \pm 0.009 & \pm 0.001 & \pm 0.009 \\
\hline 199.1 & 0.8 & 0.436 & 2.916 & 0.361 & 2.485 & 0.246 & 1.485 & 0.157 & 0.567 \\
\hline & & \pm 0.004 & \pm 0.030 & \pm 0.001 & \pm 0.003 & \pm 0.001 & \pm 0.007 & \pm 0.000 & \pm 0.003 \\
\hline 224.3 & 0.6 & 0.172 & 0.223 & 0.107 & 0.333 & 0.100 & 0.252 & 0.086 & 0.200 \\
\hline & & \pm 0.000 & \pm 0.001 & \pm 0.000 & \pm 0.001 & \pm 0.000 & \pm 0.009 & \pm 0.001 & \pm 0.009 \\
\hline
\end{tabular}

Table 3. Hydraulic parameters $\left(C_{1}\right.$ and $\left.C_{2}\right)$, unsaturated hydraulic conductivity $\left(K_{u}\right)$, and sorptivity $(S)$ values calculated from the cumulative infiltration data in baled switchgrass at $\mathbf{- 0 . 2} \mathbf{~ c m}$ of tension and variable moisture contents $(M)$ and dry matter densities.

\begin{tabular}{|c|c|c|c|c|c|c|c|c|c|c|c|c|}
\hline \multirow[b]{2}{*}{$\begin{array}{c}M \\
\text { (\% w.b.) }\end{array}$} & \multicolumn{4}{|c|}{$174.1 \pm 3.2 \mathrm{~kg} \mathrm{~m}^{-3}$} & \multicolumn{4}{|c|}{$199.1 \pm 1.4 \mathrm{~kg} \mathrm{~m}^{-3}$} & \multicolumn{4}{|c|}{$224.3 \pm 1.1 \mathrm{~kg} \mathrm{~m}^{-3}$} \\
\hline & $\begin{array}{c}C_{1} \\
\left(\times 10^{-6}\right. \\
\left.\mathrm{cm} \mathrm{s}^{-1}\right)\end{array}$ & $\begin{array}{c}C_{2} \\
\left(\times 10^{-6}\right. \\
\left.\mathrm{cm} \mathrm{s}^{-1 / 2}\right)\end{array}$ & $\begin{array}{c}K_{u} \\
\left(\mathrm{~cm} \mathrm{~s}^{-1}\right)\end{array}$ & $\begin{array}{c}S \\
\left(\mathrm{~cm} \mathrm{~s}^{-1 / 2}\right)\end{array}$ & $\begin{array}{c}C_{1} \\
\left(\times 10^{-6}\right. \\
\left.\mathrm{cm} \mathrm{s}^{-1}\right)\end{array}$ & $\begin{array}{c}C_{2} \\
\left(\times 10^{-6}\right. \\
\left.\mathrm{cm} \mathrm{s}^{-1 / 2}\right)\end{array}$ & $\begin{array}{c}K_{u} \\
\left(\mathrm{~cm} \mathrm{~s}^{-1}\right)\end{array}$ & $\begin{array}{c}S \\
\left(\mathrm{~cm} \mathrm{~s}^{-1 / 2}\right)\end{array}$ & $\begin{array}{c}C_{1} \\
\left(\times 10^{-6}\right. \\
\left.\mathrm{cm} \mathrm{s}^{-1}\right)\end{array}$ & $\begin{array}{c}C_{2} \\
\left(\times 10^{-6}\right. \\
\left.\mathrm{cm} \mathrm{s}^{-1 / 2}\right)\end{array}$ & $\begin{array}{c}K_{u} \\
\left(\mathrm{~cm} \mathrm{~s}^{-1}\right)\end{array}$ & $\begin{array}{c}S \\
\left(\mathrm{~cm} \mathrm{~s}^{-1 / 2}\right)\end{array}$ \\
\hline 10.6 & 0.779 & 5.805 & 0.272 & 2.103 & 0.437 & 2.916 & 0.126 & 1.219 & 0.172 & 0.223 & 0.024 & 0.539 \\
\hline 22.2 & 0.726 & 4.948 & 0.184 & 1.276 & 0.361 & 2.485 & 0.103 & 0.939 & 0.107 & 0.333 & 0.028 & 0.465 \\
\hline 29.7 & 0.539 & 2.958 & 0.145 & 0.990 & 0.246 & 1.485 & 0.084 & 0.465 & 0.100 & 0.252 & 0.011 & 0.168 \\
\hline 40.5 & 0.299 & 1.601 & 0.073 & 0.677 & 0.157 & 0.567 & 0.061 & 0.155 & 0.086 & 0.200 & 0.019 & 0.048 \\
\hline
\end{tabular}


its fluid flow. Higher flow rates were also attained in miscanthus bales at the highest dry bale density $\left(225 \mathrm{~kg} \mathrm{~m}^{-3}\right)$ due to the greater void space and increased pore connectivity compared to switchgrass. These results indicated a strong correlation between the saturated hydraulic conductivity of the bales and other intrinsic properties, such as surface roughness, size, geometry, and stratification of the material.

The matric suction of unsaturated switchgrass was also assessed at varying bale densities and moisture contents using the contact filter paper method, with the van Genuchten parameters ranging between 0.235 and $0.270 \mathrm{~m}^{-1}$ for $\alpha$ and between 5.415 and 10.345 for $n$, depending on the bale density. Infiltration tests were also carried out on 36 bales of switchgrass with a minidisk infiltrometer. The curve-fitting parameters of Philip's two-term equation ranged between 0.086 and $0.0779 \mathrm{~cm} \mathrm{~s}^{-1}$ for $C_{1}$ and between 0.200 and $5.805 \mathrm{~cm} \mathrm{~s}^{-1 / 2}$ for $C_{2}$, depending on the bale density and moisture content. Likewise, the unsaturated hydraulic conductivity ranged between 0.019 and $0.272 \mathrm{~cm} \mathrm{~s}^{-1}$, while sorptivity ranged between 0.048 and $2.103 \mathrm{~cm} \mathrm{~s}^{-1 / 2}$, depending on the bale density $(\mathrm{p}<0.01)$ and moisture content $(\mathrm{p}<0.02)$. The adhesive forces between the water and switchgrass impeded the flow rates observed under unsaturated conditions.

Although this study provides a good measure of the initial hydraulic conductivity of small rectangular bales, further research is recommended to address the hydraulic properties over time as the material breaks down, as well as in larger bales, which would likely result in a decline in hydraulic conductivity due to the additional resistance to flow that would be encountered through the bulk material.

\section{ACKNOWLEDGEMENTS}

The authors sincerely acknowledge the financial support of the USDA National Institute for Food and Agriculture (NIFA) Biomass Research and Development Initiative Grant No. 2011-10006-30363. This is Publication No. 18-04-033 of the Kentucky Agricultural Experiment Station and is published with the approval of the Director. This work is supported by the USDA National Institute of Food and Agriculture, Hatch Multistate under 1002344 and 1003563.

\section{REFERENCES}

Alvarado-Morales, M., Gunnarsson, I. B., Fotidis, I. A., Vasilakou, E., Lyberatos, G., \& Angelidaki, I. (2015). Laminaria digitata as a potential carbon source for succinic acid and bioenergy production in a biorefinery perspective. Algal Res., 9, 126-132. https://doi.org/10.1016/j.algal.2015.03.008

ASABE. (2007). S358.2: Measuring forage moistures. St. Joseph, MI: ASABE.

ASTM. (1992). D 5298-92. Standard test method for measurement of soil potential (suction) using filter paper. West Conshohocken, PA: ASTM International.

Berry, P. L., \& Vickers, B. (1975). The consolidation of fibrous peat. J. Geotech. Eng., 101(8), 741-753.

Christianson, L., Castello, A., Christianson, R., Helmers, M., \& Bhandari, A. (2010). Hydraulic property determination of denitrifying bioreactor fill media. Appl. Eng. Agric., 26(5), 849854. https://doi.org/10.13031/2013.34946

Chun, J. A., Cooke, R. A., Eheart, J. W., \& Kang, M. S. (2009). Estimation of flow and transport parameters for woodchip-based bioreactors: I. Laboratory-scale bioreactor. Biosyst. Eng., 104(3), 384-395. https://doi.org/10.1016/j.biosystemseng.2009.06.021

Custer, M. H., Sweeten, J. M., Reddell, D. L., \& Egg, R. P. (1990). Hydraulic conductivity of chopped sorghum. Trans. ASAE, 33(4), 1275-1280. https://doi.org/10.13031/2013.31468

Darr, M. J., \& Shah, A. (2012). Biomass storage: An update on industrial solutions for baled biomass feedstocks. Biofuels, 3(3), 321-332. https://doi.org/10.4155/bfs. 12.23

Feyereisen, G. W., \& Christianson, L. E. (2015). Hydraulic flow characteristics of agricultural residues for denitrifying bioreactor media. Appl. Eng. Agric., 31(1), 89-96. https://doi.org/10.13031/aea.31.10552

Hillel, D. (1998). Environmental soil physics. San Diego, CA: Academic Press.

Kemmerer, B., \& Liu, J. (2012). Large square baling and bale handling efficiency: A case study. Agric. Sci., 3(2), 178-183. https://doi.org/10.4236/as.2012.32020

Lambe, T. W., \& Whitman, R. V. (1969). Soil Mechanics. New York, NY: Wiley \& Sons.

Lau, A., \& Jofriet, J. C. (1988). Silage pressures at saturation in a tower silo. Canadian Agric. Eng., 30(1), 83-92.

Lefebvre, G., Langlois, P., Lupien, C., \& Lavallee, J.-G. (1984). Laboratory testing and in situ behaviour of peat as embankment foundation. Canadian Geotech. J., 21(2), 322-337. https://doi.org/10.1139/t84-033

Nokes, S. E., Lynn, B. C., Rankin, S., Knutson, B., Montross, M. D., \& Flythe, M. (2014). On-farm integrated high-solids processing system for biomass. U.S. Patent No. 9,376,697.

Perlack, R. D., Wright, L. L., Turhollow, A. F., Graham, R. L., Stokes, B. J., \& Erbach, D. C. (2005). Biomass as feedstock for a bioenergy and bioproducts industry: the technical feasibility of a billion-ton annual supply. Washington, DC: U.S. Department of Energy. Retrieved from

https://www1.eere.energy.gov/bioenergy/pdfs/final_billionton_v ision_report2.pdf

Philip, J. R. (1957). The theory of infiltration: 4. Sorptivity and algebraic infiltration equations. Soil Sci., 84(3), 257-264.

Richard, T. L. (2010). Challenges in scaling up biofuels infrastructure. Science, 329(5993), 793-796. https://doi.org/10.1126/science.1189139

Richards, L. A. (1931). Capillary conduction of liquids through porous media. J. Appl. Physics, 1(5), 318-333. https://doi.org/10.1063/1.1745010

Richardson, J., Bjorheden, R., Hakkila, P., Lowe, A. T., \& Smith, C. T. (2006). Bioenergy from sustainable forestry: Guiding principles and practice. Dordrecht, The Netherlands: Springer Science \& Business Media.

Robertson, W. D., Yeung, N., VanDriel, P. W., \& Lombardo, P. S. (2005). High-permeability layers for remediation of ground water; Go wide, not deep. Ground Water, 43(4), 574-581. https://doi.org/10.1111/j.1745-6584.2005.0062.x

Sahoo, K., \& Mani, S. (2017). Techno-economic assessment of biomass bales storage systems for a large-scale biorefinery. Biofuels Bioprod. Biorefining, 11(3), 417-429. https://doi.org/10.1002/bbb.1751

Seki, K. (2007). SWRC fit: A nonlinear fitting program with a water retention curve for soils having unimodal and bimodal pore structure. Hydrol. Earth Syst. Sci., 4(1), 407-437. https://doi.org/10.5194/hessd-4-407-2007

Selig, M. J., Hsieh, C. W., Thygesen, L. G., Himmel, M. E., Felby, C., \& Decker, S. R. (2012). Considering water availability and the effect of solute concentration on high-solids saccharification of lignocellulosic biomass. Biotech. Prog., 28(6), 1478-1490. https://doi.org/10.1002/btpr.1617

Shi, J., Chinn, M. S., \& Sharma-Shivappa, R. R. (2008). Microbial pretreatment of cotton stalks by solid-state cultivation of 
Phanerochaete chrysosporium. Bioresour. Tech., 99(14), 65566564. https://doi.org/10.1016/j.biortech.2007.11.069

Shinners, K. J., Binversie, B. N., Muck, R. E., \& Weimer, P. J. (2007). Comparison of wet and dry corn stover harvest and storage. Biomass Bioenergy, 31(4), 211-221. https://doi.org/10.1016/j.biombioe.2006.04.007

Smith, W. A., Bonner, I. J., Kenney, K. L., \& Wendt, L. M. (2013). Practical considerations of moisture in baled biomass feedstocks. Biofuels, 4(1), 95-110. https://doi.org/10.4155/bfs.12.74

Sokhansanj, S., Mani, S., Turhollow, A., Kumar, A., Bransby, D., Lynd, L., \& Laser, M. (2009). Large-scale production, harvest, and logistics of switchgrass (Panicum virgatum $\mathrm{L}$.): Current technology and envisioning a mature technology. Biofuels Bioprod. Biorefining, 3(2), 124-141.

https://doi.org/10.1002/bbb.129

Tang, J., \& Jofriet, J. C. (1991). Hydraulic conductivity of wholeplant corn silage. Canadian Agric. Eng., 33(1), 161-167.

Van Driel, P. W., Robertson, W. D., \& Merkley, L. C. (2006). Denitrification of agricultural drainage using wood-based reactors. Trans. ASABE, 49(2), 565-573.

https://doi.org/10.13031/2013.20391
Warrick, A. W., Broadbridge, P., \& Lomen, D. O. (1992). Approximations for diffusion from a disc source. Appl. Math. Model., 16(3), 155-161. https://doi.org/10.1016/0307904X(92)90067-D

Xie, P. J., Huang, L. X., Zhang, C. H., \& Zhang, Y. L. (2016). Nutrient assessment of olive leaf residues processed by solidstate fermentation as an innovative feedstuff additive. J. Appl. Microbiol., 121(1), 28-40. https://doi.org/10.1111/jam.13131

Yao, W., \& Nokes, S. E. (2014). First proof of concept of sustainable metabolite production from high-solids fermentation of lignocellulosic biomass using a bacterial co-culture and cycling flush system. Bioresour. Tech., 173, 216-223. http://dx.doi.org/10.1016/j.biortech.2014.08.113

Yao, Z., \& Jofriet, J. C. (1992). Hydraulic conductivity of alfalfa silage. Trans. ASAE, 35(4), 1291-1296. https://doi.org/10.13031/2013.28732

Zhang, R. (1997). Determination of soil sorptivity and hydraulic conductivity from the disk infiltrometer. SSSA J., 61(4), 10241030.

https://doi.org/10.2136/sssaj1997.03615995006100040005x 